\title{
WEB-BASED MODEL OF MULTIPLE CRITERIA ETHICAL DECISION-MAKING FOR ETHICAL BEHAVIOUR OF STUDENTS
}

\author{
Artūras Kaklauskas¹, Edmundas Kazimieras Zavadskas², Rita Budzevičiené ${ }^{3}$ \\ Vilnius Gediminas Technical University, \\ Institute of Internet and Intelligent Technology, \\ Saulètekio al. 11, LT-10223 Vilnius, Lithuania \\ E-mails: 19arturas.kaklauskas@st.vgtu.lt; ${ }^{2}$ edmundas.zavadskas@adm.vgtu.lt; ${ }^{3}$ ritabudzeviciene@gmail.com \\ Received 15 May 2007; accepted 6 November 2008
}

\begin{abstract}
Lately, distance studies, which are attempting at the best possible education for students and satisfaction of as many of their study needs as possible, are gaining wider popularity. Online questionnaires are increasingly used to get detailed opinions of distance learning students on various issues of studies. During the project EURASIA, it was identified that VEBER online questionnaire can be a useful tool for VGTU beyond the scope of the project EURASIA. An online questionnaire has been developed to facilitate the process of surveying related to implementation of the project EURASIA. The assessments helped to recognise that this tool helps VGTU to enhance its institutional system related to e-learning. Having identified the potential of this tool outside the scope of the EURASIA to project, further experiments have been carried out to assess how this tool can be further developed to accommodate the requirements of the project EURASIA other institutional systems. The research showed that distance learning students not only want to express their opinion about the study process, but also to be active participants in shaping strategic alternatives of the study process by electronic means. In order to implement this idea, the authors proposed the Web-based Model of Multiple Criteria Ethical Decision-Making for Ethical Behaviour of Students and used as a basis to develop the Ethical Web-Based Decision Support System (E-DS). Using the features of the VEBER online questionnaire, the developed Model and the E-DS System, the process of distance learning can be additionally humanized and adjusted to ethical norms, which would have a positive effect on the whole distance learning process. Thus, the institutions participating in the project EURASIA or offering distance learning studies could use the features of VEBER online questionnaire, the developed Model and the E-DS System in their activities. It would stimulate more efficient application of moral norms in the distance learning process.
\end{abstract}

Keywords: distance learning, EURASIA project, Ethical Decision-Making Models, VEBER online questionnaire, Decision Support System

\section{Introduction}

The e-learning Master's degree studies "Real Estate Management" were introduced at Vilnius Gediminas Technical University (VGTU) in 1999, Master's degree studies "Construction Economics" from 2000, and Master's degree studies "Internet Technologies and Real Estate Business" from 2003 (seehttp://odl. vgtu.lt/). There are currently 226 Master students from all over Lithuania studying in these three e-learning Master programs. In order to get the opinion of learners, traditional student surveys were frequent. The participation in the project EURASIA allowed to organise e-surveys. A survey of distance learning students on ethical issues of studies is reviewed in the article as an example.

The VEBER online questionnaire has been used within VGTU distance learning environment to adminis- ter student feedback questionnaires and surveys (see http://odl.vtu.lt/index.php?lang=lt\&menuitem=tr_apklausos). With the success of the VEBER online questionnaire being used in VGTU, the intention of joining institutional systems in development process within the EURASIA project is to share the experience and the technology across all the partners and beyond. The practical application of VEBER Online Questionnaire (ethical behaviour of distance learning students at VGTU) within VGTU e-learning environment and proposals for joining institutional systems in development process within the EURASIA project are briefly analyzed in the paper on the basis of ethical questions. How can one determine a truthful, ethical and efficient decision of students, if it itself influences and is influenced by different university stakeholders? In addition, here there may be a vast diversity of ethical alternative variants of the solution when in the course 
of altering the solutions and the constituent parts of the external environment, the truthfulness, ethics and efficiency of the solution can also change. Moreover, the goals of different university stakeholders are unequally significant when judging from different points of view. For example, the most appropriate response to student cheating depends in large part on the goals of the institution. If the primary goal is simply to reduce cheating, then there is a variety of strategies to consider, including increased proctoring, encouraging faculty to use multiple versions of exams and not to recycle old tests and exams, aggressively using plagiarism detection software, and employing stronger sanctions to punish offenders. But while such strategies are likely to reduce cheating, McCabe and Trevino (1996) cannot imagine many people would want to learn in such an environment. As educators, they owe our students more than this, especially when cheating may reflect cynicism about what they perceive as eroding moral standards in the academy and in society.

Also, each campus constituency tends to shift the "blame" for cheating elsewhere. This is a major problem. Many students argue, with some justification, that campus integrity policies are ill-defined, outdated, biased against students, and rarely discussed by faculty. They also fault faculty who look the other way in the face of obvious cheating. They are even more critical of faculty who, taking "the law" into their own hands when they suspect cheating, punish students without affording them their "rights" under the campus integrity policy. Many faculty members believe that these campus policies are overly bureaucratic and legalistic and that they often find "guilty" students innocent. Some faculty argue that they are paid to be teachers, not police, and that, if students have not learned the difference between right and wrong by the time they get to college, it is not their job to teach them - especially in a publish-or-perish world. Although the evidence suggests otherwise, many also believe it is too late to change students behaviour at this point (McCabe and Trevino 1996).

Today's students are more concerned about the reaction of their contemporaries and the university administration to the norms of honest behaviour promoted by lecturers and administration than about the norms themselves. Indeed, students expect the Rector's office to declare how they should become honest, noncheating and respectful towards teaching and learning. Even when students hear the statements but watch other students cheating and lecturers being tolerant by ignoring, students will take cheating as a means to pass an exam with a better possible mark. Many students ask: "If lecturers are not concerned about cheating, why should I be?"

The authors have developed the Web-based Model of Multiple Criteria Ethical Decision-Making for Ethical Behaviour of Students and the Ethical Web-Based Decision Support (E-DS) System, which are briefly analysed further in the article.

\section{Web-based Model of Multiple Criteria Ethical Decision-Making for Ethical Behaviour of Students}

Corey et al. (1998) noted that because ethical codes cannot be applied in a rote manner and they are incomplete guidelines that reflect the values of the majority, practitioners are more likely to respond to a dilemma based on fundamental principles. The proposed Web-based Model of Multiple Criteria Ethical Decision-Making for Ethical Behaviour of Students is based on ethical principles of autonomy, beneficence, nonmaleficence, justice, and fidelity that are viewed as fundamentals of the stages that make up ethical decision-making. Also, the proposed Model is based on decision-making principles (i.e. principle of life cycle's analysis, principle of the interrelation of various sciences, principle of multi-variant design and multiple criteria analysis of ethical alternatives and principle of close interrelation between the alternative's priority and the interested parties and their aims). The decisionmaker's freedom of choice is stressed in the principle of autonomy. The stakeholder is encouraged to take responsibility for his/her actions and assess the effects of these actions on others. According to the principle of beneficence it is important to meet the integrated university stakeholders (students, student community, lecturers, professors, deans, the Rector's Office, etc.) needs, e.g. physical, economical, social, political, emotional, spiritual, etc. The principle of nonmaleficence is strongly linked to the principle of beneficence and means doing no harm to others.

The principle of justice means the support of equal allocation of burdens and benefits among all university stakeholders. For example, universities must be the places where all of the campus, including the student community, lecturers and the Rector's Office, are actively cooperating to achieve their goals. Almost two decades ago, this fact was noted by Boyer (1987), who claimed: "honesty cannot be divided. If high ethical norms are applicable to students, university staff must also have a perfect record".

Efforts are made to achieve a truthful, ethical and efficient solution, i.e. to optimize the life cycle of the ethical alternative (principle of life cycle's analysis). 
The problems of truthfulness, ethics and efficiency of the solution may be successfully solved only when the achievements of various sciences, such as philosophy, ethics, Law, psychology, management, administration, economics, etc. are used. The use of a principle of multi-variant design and multiple criteria analysis makes it possible to develop many ethical alternative versions and carry out their ethical and other kinds of optimization throughout life cycle of the alternative.

The above principles are landmarks of the proposed Model and act as support for solving the dilemma of ethical behaviour of students. In different situations a few ethical principles sometimes oppose each other, and grading them is difficult.

According to Garfat and Ricks (1995), ethics is no longer about determining "right answers", but whether and how the decision maker decides what action to take. Ethical decision-making is a process governed by ethical principles. Also, when confronted with a complicated ethical dilemma that is not evidently analyzed in codes of ethics, the decision-maker should check with an ethical decision-making model.
Based on the analysis of the above ethical decision making models (Bombara 2002; Cottone and Claus 2000; Doolittle and Herrick 1992; Griene and Kropf 1993; Robson et al. 2000; Tymchuk 1986; Walden et al. 1990) a Web-based Model of Multiple Criteria Ethical Decision-Making for Ethical Behaviour of Students was developed by the authors of this paper. Some stages of the Model described in the paper (see Stages 1-3, $8,9)$ are partly similar to the stages of the models proposed by some other authors (Bombara 2002; Cottone and Claus 2000; Doolittle and Herrick 1992; Griene and Kropf 1993; Robson et al. 2000; Tymchuk 1986; Walden et al. 1990). All other stages differ in principle, since the methods of multiple criteria analysis created by authors are applied and also, this Model is meant for the build-up of the Web-based decision support system.

The proposed Web-based Model of Multiple Criteria Ethical Decision-Making for Ethical Behaviour of Students provides a logical system and gradually guides and helps the stakeholder in the creation of acting in a way that includes moral behavior. These stages are the main steps of action and can be shaped into the framework of particular circumstances (Fig. 1).

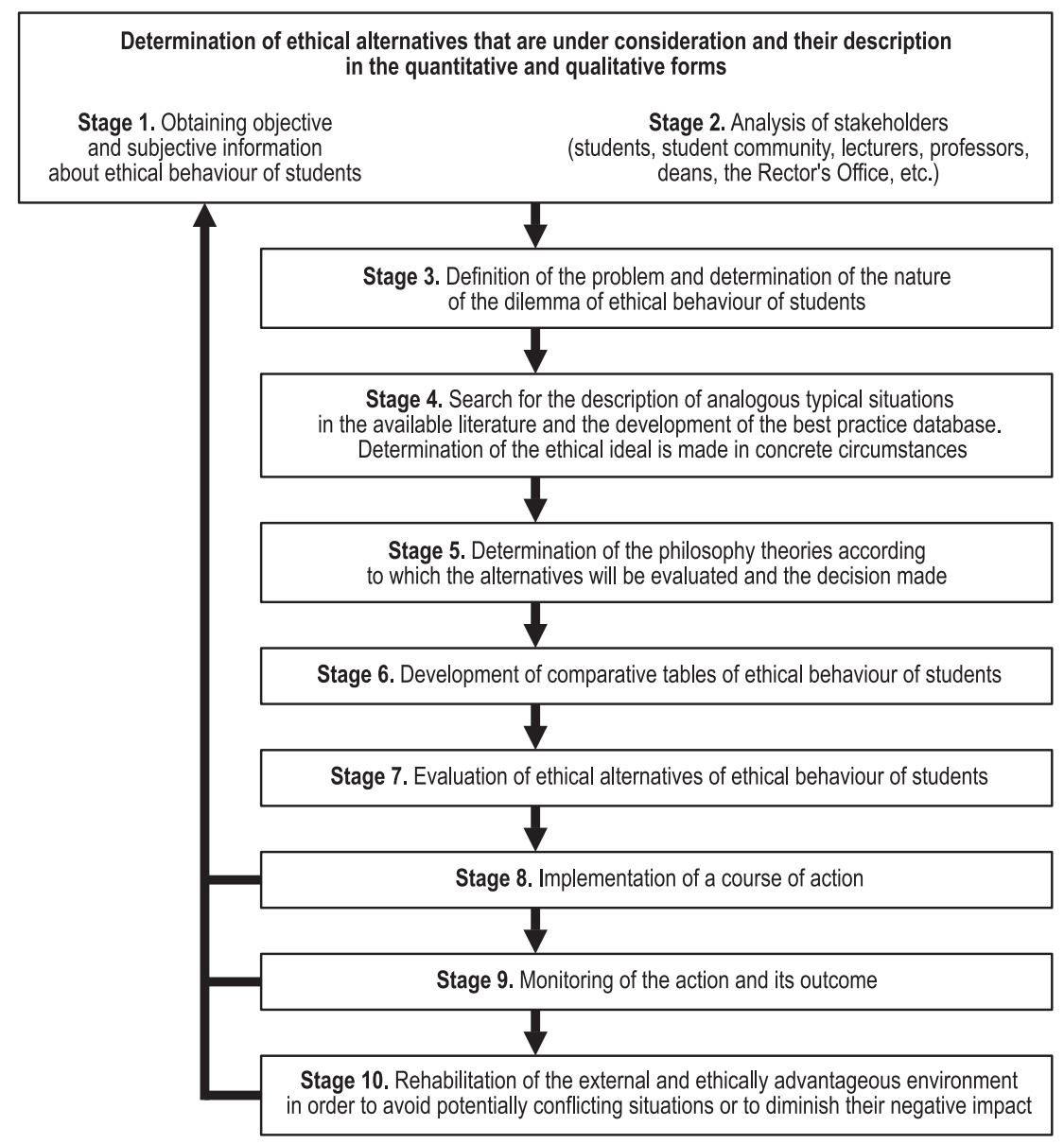

Fig. 1. Main stages of the developed Web-based Model of Multiple Criteria Ethical Decision-Making for Ethical Behaviour of Students and their relation to EDSS 
The ten stages of Web-based Model of Multiple Criteria Ethical Decision-Making for Ethical Behaviour of Students are as follows:

Stage 1. Obtaining as much objective and subjective information about ethical behaviour of students (historical information, institutional, administration, legal, societal expectations and limitations, ethical principles involved, identified conflicts, etc.) as possible. Further, if possible, the decision-makers have to develop suitable arguments on diverse aspects of the dilemma so as to have a high-quality perception of the range of concerns and advantages for each position.

Stage 2. Analysis of university stakeholders (students, student community, lecturers, professors, deans, the Rector's Office, etc.). The university stakeholders are identified as the interested parties who are directly or indirectly influenced by the decision that is to be made. For a better understanding of the current situation, discussions among the various interested parties are often necessary. Also, some ethical dilemmas can be prevented through dialogue between university stakeholders. The discussion should engage all those who are the key university stakeholders, some of whom may be the decision-makers and some of whom may be influenced by the decision. The reaction that results from such discussions clears personal values while determining value conflicts. University stakeholders have to act as a team in an effort to come to some commonly suitable decisions. All university stakeholders should accept some responsibility for the existing ethical behaviour of students and have to be a part of any proposed decision. The personal values, theoretical orientation, experience and other stakeholder features play a part in achieving ethical decisions. University stakeholders have to analyze their own value judgments, moral codes, experience with similar ethical behaviour of students, and decide how to avoid injecting personal biases into decisions. Also, the decision-maker must examine the values of other university stakeholders. Compromises that may diminish harmful consequences should be analyzed. On the grounds of the Model offered, decisions may be made from the viewpoint of one, several or all the interested groups.

Stage 3. Definition of the problem (conflicting ethical principles, value conflicts) and determination of the nature of the dilemma of ethical behaviour of students. According to Joseph (1983) an ethical dilemma is a conflict in which a person must make a choice between several correct and conflicting decisions, generally with some negative consequences. Traditionally, dilemma (ethical, legal/moral, etc.) involves a choice between competing goods with possible harmful consequences.
Assessment of a dilemma involves the detection of different conflicting ethical principles. Typically, the ethical dilemmas are inherently problem ethical behaviour of students that do not lead to easy decisions and there is no right or wrong one that can be easily recognized. Therefore, conflict between values of the different university stakeholders leads to an ethical dilemma where there is no easy solution and no right or wrong answer to ethical behaviour of students.

Stage 4. Determination of the philosophy theories (e.g., utilitarianism, deontology, justice, etc.) according to which the ethical alternatives will be evaluated and the decision made. Determination of the ethical ideal is made in concrete circumstances.

Stage 5. Search for the description of analogous typical situations of ethical behaviour of students in the available literature and the development of the best practice database.

Stage 6. Development of comparative tables of ethical behaviour of students. The aim at this stage is to build options for the decision, in preparation for making the ethical decision and arguing for the choice. Results of the generation of all possible courses of action have been submitted in the table. By submission, such a display of the multiple criteria comparisons can become more effectively supported. As in any problematic circumstances, the university stakeholders search for potential compromises by trying to find one that is most ethical and with the least negative consequences.

Stage 7. Evaluation of ethical alternatives of ethical behaviour of students. A decision-maker must examine a large number of ethical alternatives, each of which is surrounded by a considerable amount of information. Ethical alternatives are analyzed along with the involved ethical principles and philosophical theories. The expectations and obligations of different university stakeholders are then considered. Ethical alternative solutions are compared in terms of the possible outcomes and according to the selected philosophical theories. Following on from gathering this information, the priority and utility degree of the ethical alternatives is then calculated by using various multiple criteria methods proposed by different researchers (Brauers and Zavadskas 2006; Ginevičius 2008; Ginevičius and Krivka 2008; Ginevičius et al. 2008; Kaklauskas and Pruskus 2005; Kaklauskas et al. 2007a, b, 2003; Mickaitytè et al. 2008; Mitkus and Trinkūnienè 2008; Shevchenko et al. 2008; Turskis 2008; Ustinovichius et al. 2007; Viteikienè and Zavadskas 2007; Zavadskas and Turskis 2008; Zavadskas et al. 2008a, b, 2006). The utility degree is directly proportional to the rela- 
tive effect of the values and weights of the criteria and is considered as the efficiency of the alternative. This helps a decision-maker to decide what ethical alternative best fits the ethical behaviour of students that is under evaluation (i.e. the best solution achievable given the available resources and the circumstances of the dilemma). Several decisions will have priority and the choice is according to the preferences of different university stakeholders and philosophy theories (e.g., utilitarianism, deontology, justice, etc.)

Priority of decisions depends a lot on whether one group or several interested groups make the decision, because different university stakeholders bring diverse experiences, beliefs, and moral codes into the decisionmaking process. The Ethical Web-Based Decision Support System (EDSS) developed on the basis of this model enables the analysis of ethical alternatives from the viewpoint of different interested groups. However, there is seldom an ideal decision to an ethical dilemma.

Stage 8. Implementation of a course of action. Implementing the decision may be the most difficult stage of the decision-making process. Ethical decisions are individual choices that may not be shared with other university stakeholders. The decision-maker may be in a solitary situation in implementing some decisions and willing to admit the consequences of a decision that is not supported by others.

Stage 9. Monitoring of the action and its outcome.

Stage 10. Rehabilitation of the external and ethically advantageous environment in order to avoid potentially conflicting ethical behaviour of students or to diminish their negative impact. Truthfulness, ethics and efficiency of the solution depend on the micro- and macro-levels of the external environment. Macro-level factors of the external environment, such as religion, the existing cultural, social, ethical dimensions of the country, the executed university policy and the society, influence the arising ethical problems and the ethical solution-making. The micro-level factors (the university stakeholders, the applied formal code of ethics, rules, criteria of ethical behaviour, ethical standards, codes of conduct) stipulate the ethical solution-making to a significant degree as well. Therefore, on the grounds of cumulative experience it is suggested that there be changes under these possibilities of the surrounding environment in order to decrease the possibility of a conflict situation arising in ethical behaviour of students or to diminish their negative impact. Developing an ethical environment also provides a background for ethical questioning, significant exchange, informed decision-making, and human consensus, in which all university stakeholders are satisfied. A few trends of rehabilitation of the external and ethically advantageous environment in order to avoid potentially conflicting ethical behaviour of students are following up.McCabe and Trevino (1996) propose to involve the whole campus community (students, faculty, and administrators) to effectively educate a student. If university's only goal is to reduce cheating, there are far simpler strategies university can employ. But if university has the courage to set our sights higher, and strives to achieve the goals of a liberal education, the challenge is much greater. Among other things, it is a challenge to develop students who accept responsibility for the ethical consequences of their ideas and actions. University's goal should not simply be to reduce cheating; rather, university's goal should be to find innovative and creative ways to use academic integrity as a building block in university efforts to develop more responsible students and, ultimately, more responsible citizens. University campuses must become places where the entire "village" - the community of students, faculty, and administrators - actively works together to achieve this goal. As Ernest Boyer observed almost two decades ago - (Boyer 1987), "integrity cannot be divided. If high standards of conduct are expected of students, colleges must have impeccable integrity themselves. Otherwise the lessons of the 'hidden curriculum' will shape the undergraduate experience. Colleges teach values to students by the standards they set for themselves".

Many of the USA students surveyed by McCabe and Trevino (1996) were troubled by the failure of their institution, and often its faculty, to address the issue of cheating. Because they believed that weak institutional policies and unobservant or unconcerned faculty were "allowing" others to cheat and, thereby, to gain an unfair advantage, students viewed cheating as a way to level the playing field. This was a particular problem on large campuses and in courses with large enrollments-environments where, arguably, it is harder to establish a strong, positive community culture $(\mathrm{Co}-$ rey et al. 1998).

Students claimed that while they see numerous cases of cheating in higher education institutions and in the society, the role of disciplinary actions is important striving to reduce the amount of cheating in university.

McCabe and Trevino (1996) in the fall of 1990 surveyed students at thirty-one of the US's most competitive colleges and universities. Fourteen institutions had traditional academic honor codes, and seventeen did not, having chosen instead to "control" student dishonesty through such strategies as the careful proctoring of exams. The existence of a code did not always result in lower levels of cheating. 
The above-described Web-based Model of Multiple Criteria Ethical Decision-Making for Ethical Behaviour of Students can provide decision-makers with quite a secure means of making difficult ethical decisions. This model can also help university stakeholders to make the best feasible decision in certain given circumstances. The proposed Model does not make ethical decisions, but explains the process for investigating ethical behaviour of students.

Based on the proposed Model of Multiple Criteria Ethical Decision-making an Ethical Multiple Criteria Decision Support Web-Based System (http://dss.vtu. 1t/ethic/index_eng.htm) was developed by the authors. In order to demonstrate practical application of the Model, development of comparative tables of ethical behaviour of students and evaluation of ethical alternatives of ethical behaviour of students were carried out (Stages 6 and 7 of the Model; see Chaper 3).

In order to demonstrate practical application of the Model, a survey was carried out in Vilnius Gediminas Technical University (VGTU). The survey gives a more detailed explanation of Stages 1 and 2 of the Model (see Chaper 4).

\section{Development of comparative tables of ethical behaviour of students and evaluation of ethical alternatives of ethical behaviour of students}

\subsection{Development of comparative tables of ethical behaviour of students}

The determination of the utility degree and value of the alternative under investigation and establishment of the priority order for its implementation do not present much difficulty if the criteria numerical values and weights have been obtained and the multiple criteria decision-making methods are used.

All criteria are calculated for the whole alternative. The process of determining the system of criteria, their initial weights and qualitative criteria numerical values of the alternative under investigation is based on the use of various expert methods. The determination of quantitative criteria numerical values is based on the use of various statistical methods, analysed alternatives, recommendations, reference books and other documents. For example, values of qualitative criteria may be obtained as follows by applying the expert methods:

- the best suitable alternative is chosen according to a specific criterion;

- the considered criterion of the selected best alternative is set equal to the magnitude of one point $\left(x_{g e r}=1\right)$;
- the ratio $\left(p_{i}\right)$ amongst all the rest alternatives of the corresponding criterion magnitudes and the best criterion magnitude is determined;

- the criteria are given relative values $\left(x_{i}=p_{i}\right)$;

- relative values of all criteria are recalculated so that their sum makes one.

In a similar way, the initial weights of the criteria may be determined. The magnitude of weights indicates how many times one criterion is more/less significant than the other one in a multiple criteria evaluation of alternatives.

The results of the comparative analysis of the alternatives are presented as a grouped decision-making matrix where columns contain $n$ alternatives being considered, while all quantitative and conceptual information pertaining to them is found in lines (Table 1).

Quantitative and conceptual description of the research object provides the information about various aspects of alternatives (i.e. ethical, social, economical, legislative, etc.). Quantitative information is based on the criteria systems and subsystems, units of measure, values and initial weights as well as the data on the alternatives' development.

Conceptual description of alternatives presents textual, graphical (schemes, graphs, diagrams, drawings), visual (videotapes) information about the alternatives and the criteria used for their definition, as well as giving the reason for the choice of this particular system of criteria, their values and weights. This part also includes information about the possible ways of multivariant design. Conceptual information is needed to make more complete and accurate evaluation of the alternatives considered. It also helps to get more useful information as well as developing a system and subsystems of criteria and defining their values and weights. In order to perform a complete study of the research object a complex evaluation of its ethical, social, economical, legislative and other aspects is needed. The diversity of aspects being assessed should follow the diversity of ways of presenting data needed for decision-making. Therefore, the necessary data may be presented in numerical, textual, graphical (schemes, graphs, charts), formula, videotape and other forms.

The grouping of the information in the matrix should be performed so as to facilitate the calculation process and to express their physical meaning. In our case the criteria system is formed from the criteria describing the alternatives which can be expressed in a quantitative form (quantitative criteria) and the criteria describing the alternatives which cannot be expressed in a quantitative form (qualitative criteria). 
Table 1. Grouped decision-making matrix of alternatives multiple criteria analysis

\begin{tabular}{|c|c|c|c|c|c|c|c|c|c|}
\hline \multicolumn{10}{|c|}{ Quantitative information pertinent to alternatives } \\
\hline \multirow[t]{2}{*}{ Criteria describing the alternatives } & \multirow[t]{2}{*}{$*$} & \multirow[t]{2}{*}{ Weight } & \multirow{2}{*}{$\begin{array}{l}\text { Measuring } \\
\text { units }\end{array}$} & \multicolumn{6}{|c|}{ Compared alternatives } \\
\hline & & & & $a_{1}$ & $a_{2}$ & $\cdots$ & $\mathrm{a}_{\mathrm{j}}$ & $\ldots$ & $a_{n}$ \\
\hline \multirow{6}{*}{$\begin{array}{l}\text { Quantitative } \\
\text { criteria }\end{array}$} & $\mathrm{z}_{1}$ & $\mathrm{q}_{1}$ & $\mathrm{~m}_{1}$ & $\mathrm{x}_{11}$ & $\mathrm{x}_{12}$ & $\cdots$ & $\mathrm{x}_{1 \mathrm{j}}$ & $\cdots$ & $\mathrm{x}_{1 \mathrm{n}}$ \\
\hline & $\mathrm{z}_{2}$ & $\mathrm{q}_{2}$ & $\mathrm{~m}_{2}$ & $\mathrm{x}_{21}$ & $\mathrm{x}_{22}$ & $\cdots$ & $\mathrm{x}_{2 \mathrm{j}}$ & $\cdots$ & $\mathrm{x}_{2 \mathrm{n}}$ \\
\hline & $\cdots$ & $\cdots$ & $\cdots$ & $\cdots$ & $\ldots$ & $\cdots$ & $\cdots$ & $\cdots$ & $\cdots$ \\
\hline & $\mathrm{z}_{\mathrm{i}}$ & $\mathrm{q}_{\mathrm{i}}$ & $\mathrm{m}_{\mathrm{i}}$ & $\mathrm{x}_{\mathrm{i} 1}$ & $\mathrm{x}_{\mathrm{i} 2}$ & $\cdots$ & $\mathrm{x}_{\mathrm{ij}}$ & $\cdots$ & $\mathrm{x}_{\mathrm{in}}$ \\
\hline & $\cdots$ & $\cdots$ & $\cdots$ & $\cdots$ & $\cdots$ & $\cdots$ & $\ldots$ & $\cdots$ & $\ldots$ \\
\hline & $\mathrm{z}_{\mathrm{t}}$ & $\mathrm{q}_{\mathrm{t}}$ & $\mathrm{m}_{\mathrm{t}}$ & $\mathrm{x}_{\mathrm{t} 1}$ & $\mathrm{x}_{\mathrm{t} 2}$ & $\cdots$ & $\mathrm{x}_{\mathrm{tj}}$ & $\ldots$ & $\mathrm{x}_{\mathrm{tn}}$ \\
\hline \multirow{6}{*}{$\begin{array}{l}\text { Qualitative } \\
\text { criteria }\end{array}$} & $\mathrm{z}_{\mathrm{t}+1}$ & $\mathrm{q}_{\mathrm{t}+1}$ & $\mathrm{~m}_{\mathrm{t}+1}$ & $\mathrm{x}_{\mathrm{t}+11}$ & $\mathrm{x}_{\mathrm{t}+12}$ & $\cdots$ & $x_{t+1 j}$ & $\cdots$ & $\mathrm{x}_{\mathrm{t}+1 \mathrm{n}}$ \\
\hline & $z_{t+2}$ & $\mathrm{q}_{\mathrm{t}+2}$ & $\mathrm{~m}_{\mathrm{t}+2}$ & $\mathrm{x}_{\mathrm{t}+21}$ & $\mathrm{x}_{\mathrm{t}+22}$ & $\cdots$ & $x_{t+2 j}$ & $\ldots$ & $\mathrm{x}_{\mathrm{t}+2 \mathrm{n}}$ \\
\hline & $\ldots$ & $\ldots$ & $\ldots$ & $\ldots$ & $\ldots$ & $\cdots$ & $\ldots$ & $\ldots$ & $\cdots$ \\
\hline & $\mathrm{z}_{\mathrm{i}}$ & $\mathrm{q}_{\mathrm{i}}$ & $\mathrm{m}_{\mathrm{i}}$ & $\mathrm{x}_{\mathrm{i} 1}$ & $\mathrm{x}_{\mathrm{i} 2}$ & $\ldots$ & $\mathrm{x}_{\mathrm{ij}}$ & $\ldots$ & $\mathrm{x}_{\text {in }}$ \\
\hline & $\cdots$ & $\ldots$ & $\cdots$ & $\ldots$ & $\ldots$ & $\cdots$ & $\ldots$ & $\cdots$ & $\ldots$ \\
\hline & $\mathrm{z}_{\mathrm{m}}$ & $\mathrm{q}_{\mathrm{m}}$ & $\mathrm{m}_{\mathrm{m}}$ & $\mathrm{x}_{\mathrm{m} 1}$ & $\mathrm{x}_{\mathrm{m} 2}$ & $\cdots$ & $x_{\mathrm{mj}}$ & $\ldots$ & $\mathrm{x}_{\mathrm{mn}}$ \\
\hline \multicolumn{10}{|c|}{ Conceptual information pertinent to alternatives (i.e. text, drawings, graphics, video tapes) } \\
\hline $\mathrm{C}_{\mathrm{f}}$ & $\mathrm{C}_{\mathrm{z}}$ & $\mathrm{C}_{\mathrm{q}}$ & $\mathrm{C}_{\mathrm{m}}$ & $\mathrm{C}_{1}$ & $\mathrm{C}_{2}$ & $\ldots$ & $\mathrm{C}_{\mathrm{j}}$ & $\ldots$ & $\mathrm{C}_{\mathrm{n}}$ \\
\hline
\end{tabular}

* The sign $\mathrm{z}_{\mathrm{i}}(+(-))$ indicates that a greater (less) criterion value corresponds to higher significance for interested parties

\subsection{A method of multiple criteria complex proportional evaluation of the alternatives}

This method assumes direct and proportional dependence of significance and priority of investigated versions on a system of criteria adequately describing the alternatives and on values and weight of the criteria. The system of criteria is determined and the values and initial weights of criteria are calculated by experts. All this information can be corrected by interested parties taking into consideration their pursued goals and existing capabilities. Hence, the assessment results of alternatives fully reflect the initial data jointly submitted by experts and interested parties (Table 2).

The determination of significance and priority of alternatives is carried out in four stages.

Stage 1. The weighted normalized decision-making matrix D is formed. The purpose of this stage is to receive dimensionless weighted values from the comparative indexes. When the dimensionless values of the indexes are known, all criteria, originally having different dimensions, can be compared. The following formula is used for this purpose:

$$
d_{i j}=\frac{x_{i j} \cdot q_{i}}{\sum_{j=1}^{n} x_{i j}}, \quad i=\overline{1, m ;} j=\overline{1, n},
$$

where $x_{i j}$ - the value of the $i$-th criterion in the $j$-th alternative of a solution; $m$ - the number of criteria; $n$ - the number of the alternatives compared; $q_{i}-$ significance of $i$-th criterion.

The sum of dimensionless weighted index values $d_{i j}$ of each criterion $x_{i}$ is always equal to the significance $q_{i}$ of this criterion:

$$
q_{i}=\sum_{j=1}^{n} d_{i j}, \quad i=\overline{1, m} ; \quad j=\overline{1, n}
$$

In other words, the value of weight $q_{i}$ of the investigated criterion is proportionally distributed among all alternative versions $a_{j}$ according to their values $x_{i j}$.

Stage 2. The sums of weighted normalized indexes describing the $j$-th version are calculated. The versions are described by minimizing indexes $S_{-j}$ and maximizing indexes $S_{+j}$. The lower value of minimizing indexes is better. The greater value of maximizing indexes is better. The sums are calculated according to the formula:

$$
S_{+j}=\sum_{j=1}^{m} d_{+i j} ; S_{-j}=\sum_{j=1}^{m} d_{-i j}, \quad i=\overline{1, m} ; j=\overline{1, n} .
$$

In this case, the values $S_{+j}$ (the greater is this value (alternative 'pluses'), the more satisfied are the interested parties) and $S_{-j}$ (the lower is this value (alterna- 
tive 'minuses'), the better is goal attainment by the interested parties) express the degree of goals attained by the interested parties in each alternative. In any case the sums of 'pluses' $S_{+j}$ and 'minuses' $S_{-j}$ of all alternatives are always respectively equal to all sums of significance of maximizing and minimizing criteria:

$$
\begin{aligned}
& S_{+}=\sum_{j=1}^{n} S_{+j}=\sum_{i=1}^{m} \sum_{j=1}^{n} d_{+i j}, \\
& S_{-}=\sum_{j=1}^{n} S_{-j}=\sum_{i=1}^{m} \sum_{j=1}^{n} d_{-i j}, \quad i=\overline{1, m} ; j=\overline{1, n} .
\end{aligned}
$$

In this way, the calculations made may be additionally checked.

Stage 3. The significance (efficiency) of comparative versions is determined on the basis of describing positive alternatives ('pluses') and negative alternatives ('minuses') characteristics. Relative significance $Q_{j}$ of each alternative $a_{j}$ is found according to the formula:

$$
Q_{j}=S_{+j}+\frac{S_{-\min } \cdot \sum_{j=1}^{n} S_{-j}}{S_{-j} \cdot \sum_{j=1}^{n} \frac{S_{-\min }}{S_{-j}}}, j=\overline{1, n} .
$$

Stage 4. Priority determination of alternatives. The greater is the criterion $Q_{j}$, the higher is the efficiency (priority) of the alternative.

The analysis of the method presented makes it possible to state that it may be easily applied to evaluating the alternatives and selecting most efficient of them, being fully aware of a physical meaning of the process. Moreover, it allowed to formulate a reduced criterion $Q_{j}$ which is directly proportional to the relative effect of the compared criteria values $x_{i j}$ and significances $q_{i}$ on the end result.

\section{Ethical Behaviour of Distance Learning Students at VGTU}

The form of a survey was selected for the research of ethical issues related to behaviour of distance learning students in the Faculty of Civil Engineering at Vilnius Gediminas Technical University. The VEBER online questionnaire of 24 questions has been used within VGTU distance learning environment to administer student feedback questionnaires and surveys (seehttp://odl.vtu.lt/index.php?lang=lt\&menuitem=tr_ap-

\begin{tabular}{|c|c|c|c|c|c|c|c|c|c|}
\hline \multicolumn{10}{|c|}{ Quantitative information pertinent to alternatives } \\
\hline \multirow{2}{*}{$\begin{array}{l}\text { Criteria describing the } \\
\text { alternatives }\end{array}$} & \multirow[t]{2}{*}{ * } & \multirow[t]{2}{*}{ Weight } & \multirow[t]{2}{*}{ Measuring units } & \multicolumn{6}{|c|}{ Compared alternatives } \\
\hline & & & & $a_{1}$ & $a_{2}$ & $\cdots$ & $a_{j}$ & $\cdots$ & $a_{n}$ \\
\hline $\mathrm{X}_{1}$ & $\mathrm{z}_{1}$ & $\mathrm{q}_{1}$ & $\mathrm{~m}_{1}$ & $\mathrm{~d}_{11}$ & $\mathrm{~d}_{12}$ & $\cdots$ & $\mathrm{d}_{1 \mathrm{j}}$ & $\cdots$ & $\mathrm{d}_{1 \mathrm{n}}$ \\
\hline$X_{2}$ & $\mathrm{z}_{2}$ & $\mathrm{q}_{2}$ & $\mathrm{~m}_{2}$ & $\mathrm{~d}_{21}$ & $\mathrm{~d}_{22}$ & $\cdots$ & $d_{2 j}$ & $\cdots$ & $\mathrm{d}_{2 \mathrm{n}}$ \\
\hline $\mathrm{X}_{3}$ & $\mathrm{z}_{3}$ & $\mathrm{q}_{3}$ & $\mathrm{~m}_{3}$ & $\mathrm{~d}_{31}$ & $d_{32}$ & $\cdots$ & $d_{3 j}$ & $\cdots$ & $d_{3 n}$ \\
\hline$\cdots$ & $\cdots$ & $\cdots$ & $\cdots$ & $\cdots$ & $\cdots$ & $\cdots$ & $\cdots$ & $\cdots$ & $\cdots$ \\
\hline $\mathrm{X}_{\mathrm{i}}$ & $\mathrm{z}_{\mathrm{i}}$ & $\mathrm{q}_{\mathrm{i}}$ & $\mathrm{m}_{\mathrm{i}}$ & $\mathrm{d}_{\mathrm{i} 1}$ & $\mathrm{~d}_{\mathrm{i} 2}$ & $\cdots$ & $\mathrm{d}_{\mathrm{ij}}$ & $\cdots$ & $\mathrm{d}_{\text {in }}$ \\
\hline$\cdots$ & $\cdots$ & $\cdots$ & $\cdots$ & $\cdots$ & $\cdots$ & $\cdots$ & $\cdots$ & $\cdots$ & $\cdots$ \\
\hline $\mathrm{X}_{\mathrm{m}}$ & $\mathrm{z}_{\mathrm{m}}$ & $\mathrm{q}_{\mathrm{m}}$ & $\mathrm{m}_{\mathrm{m}}$ & $\mathrm{d}_{\mathrm{m} 1}$ & $\mathrm{~d}_{\mathrm{m} 2}$ & $\cdots$ & $\mathrm{d}_{\mathrm{mj}}$ & $\ldots$ & $\mathrm{d}_{\mathrm{mn}}$ \\
\hline \multicolumn{4}{|c|}{$\begin{array}{l}\text { The sums of weighted normalized maximizing (alternatives 'pluses') } \\
\text { indices of the alternative }\end{array}$} & $\mathrm{S}_{+1}$ & $\mathrm{~S}_{+2}$ & $\cdots$ & $\mathrm{S}_{+\mathrm{j}}$ & $\cdots$ & $\mathrm{S}_{+\mathrm{n}}$ \\
\hline \multicolumn{4}{|c|}{$\begin{array}{l}\text { The sums of weighted normalized minimizing (alternatives 'minuses') } \\
\text { indices of the alternative }\end{array}$} & $\mathrm{S}_{-1}$ & $\mathrm{~S}_{-2}$ & $\cdots$ & $S_{-j}$ & $\cdots$ & $S_{-n}$ \\
\hline \multicolumn{4}{|c|}{ Significance of the alternative } & $\mathrm{Q}_{1}$ & $\mathrm{Q}_{2}$ & $\ldots$ & $\mathrm{Q}_{\mathrm{j}}$ & $\cdots$ & $\mathrm{Q}_{\mathrm{n}}$ \\
\hline \multicolumn{4}{|l|}{ Priority of the alternative } & $\mathrm{P}_{1}$ & $\mathrm{P}_{2}$ & $\cdots$ & $P_{j}$ & $\ldots$ & $P_{n}$ \\
\hline \multicolumn{4}{|c|}{ Utility degree of the alternative $(\%)$} & $\mathrm{N}_{1}$ & $\mathrm{~N}_{2}$ & $\ldots$ & $\mathrm{N}_{\mathrm{j}}$ & $\ldots$ & $\mathrm{N}_{\mathrm{n}}$ \\
\hline
\end{tabular}
klausos).

Table 2. Multiple criteria analysis results

* The sign $\mathrm{z}_{\mathrm{i}}(+(-))$ indicates that a greater (less) criterion value corresponds to greater significance for interested parties 
The experience of many analogical surveys (Bowers 1964; Boyer 1987) carried out in the world shows that when students think that organisers of surveys will find out the authorship of a questionnaire, then such surveys give the results which distort the real situation greatly. None of students wants to reveal his/her confidential information to the staff of the university.

Therefore, all distance learning students could answer all questions anonymously by using the VEBER online questionnaire. The survey consisted of two steps. One step when a student selects the most appropriate answer to the question. The other step when the student specifies the theory of ethics on which he/she based the answer.

Theories of ethics were introduced to students before the survey, i.e. the students were briefed on the main points of different theories of ethics. The questionnaire included four main theories of ethics: deontology, utilitarianism, justice and teleology. For example, when carrying out an analysis of university stakeholders, it is expedient to apply the utilitarianism theory. In such an analysis the objectives and needs of university stakeholders can be analyzed, various decision ethical alternatives worked out and positive and negative consequences of these ethical alternatives on university stakeholders that are under consideration can be determined. According to the utilitarianism theory, a decision whether a certain action is considered bad or good depends on its consequences and not on intentions. Utilitarianism says that what is morally right is whatever produces the greatest overall amount of pleasure, happiness, ideal values (freedom, knowledge, justice, and beauty) and preference satisfaction to as many university stakeholders as possible. The criterion of a moral action consists of those rules of conduct, which give most utility to all the university stakeholders. Actions that meet the needs of university stakeholders are considered to be good. However, when conducting such an analysis of the stakeholders' requirements various problems occur. For example, what is of the greatest good for the greatest number of university stakeholders without violating individual rights in different situations? Is it goodness, efficiency, profitability and/or pleasure? Which needs of which university stakeholders are to be given priority? How can one take into consideration the qualitative parameters (health, security, public benefit)? By using experts and multiple criteria analysis methods one can solve these problems, to some extent.
The questionnaire was published in the website at the address: <http://dss.vtu.lt/moodle/mod/questionnaire/ view.php?id=12>.

Thirty-nine distance learning students participated in the survey anonymously: 26 male (67\%) and 13 female (33\%) respondents of ages from 20 to 60 . Most students were from 20 to 30 years old (27 people; 69\%), a smaller number of respondents formed the group of ages between 30 and 40 ( 8 people; 21\%), and the least number of people were of ages from 40 to 50 and from 50 to 60 ( 2 people in each group; $5 \%$ each).

Given the question whether they would cheat during an examination, 12 students (31\%) answered that they would if they knew nothing. Slightly smaller amount of students answered that they would cheat if they were sure that they would not get caught (9 students; 23\%). Two students $(5 \%)$ would cheat during an examination. Seven students (18\%) would not cheat during an examination. Six people (15\%) would not cheat even if they knew nothing. Three students (8\%) would not cheat even if they were sure that they would not get caught. Students based their answers to the question about cheating in an examination on the following theories of ethics: deontology (6 students; $15 \%$ ), justice (23 students; 60\%), teleology (4 students; 10\%) and utilitarianism (6 students; 15\%).

Similar results have been obtained in other countries too. For example, in 1993 McCabe and Travino (1996) surveyed nine medium to large most USA competitive colleges and universities, which thirty years earlier had participated in the landmark study of college cheating conducted by Bowers (Bowers 1964). Bowers's (1964) project surveyed over five thousand students on ninetynine campuses across the USA and provided considerable insight on how often students were cheating and why. Two outcomes of McCabe and Travino (1996) project are particularly noteworthy in comparison to Bowers's results. First, there were substantial increases in self-reported test and exam cheating at these nine schools. For example, 39 percent of students completing the 1963 survey acknowledged one or more incidents of serious test or exam cheating; by 1993, this had grown to 64 percent. In 1993, many students simply did not see cheating as a big deal, so it was easier to acknowledge - especially in an anonymous survey. Second, there was no change in the incidence of serious cheating at written work; 65 percent of students in 1963 acknowledged such behavior, and 66 percent did so in 1993. However, student comments in the 1993 survey suggested that this younger generation of students was more lenient in defining what constitutes plagiarism (McCabe and Travino 1996). 
Lecturers have the most important role in the exercise of ethical standards, because students consult both their contemporaries and their lecturers about their studies process. In order to foster a proper attitude of a student, lecturers must acknowledge and validate academic honesty as the most important value. Without such acknowledgement of values, many students may find cheating meaningful, because they can revert to the secondary school strategies, i.e. cheating to get a better mark and blaming excessive loads, lack of time and providing other similar reasons, i.e. students presume that if lecturers fail to act in cases of obvious cheating they sort of invite cheating. This stimulates dissatisfaction of students who learn honestly. They feel deceived because of lecturer inactivity.

Most students, 28 people (72\%), do not consider a peek at notes as cheating, whereas other $11(28 \%)$ claim that a peek at notes may be equal to cheating. Students based their answers to the question whether a peek at notes is equal to cheating on the following theories of ethics: deontology ( 7 students; $18 \%)$, justice (16 students; 41\%), teleology (7 students; $18 \%$ ) and utilitarianism ( 9 students; $23 \%$ ).

Three students (8\%) would copy a course project or homework from another person, 5 people $(13 \%)$ possibly would copy, 9 people (23\%) possibly would not copy and 22 people (56\%) would not copy (Fig. 2 $(l e f t))$. Students based their answers to the question about copying a course project or homework from another person on the following theories of ethics (Fig. 2 (right)): deontology (6 students; 15\%), justice (19 students; 49\%), teleology (6 students; 15\%) and utilitarianism (8 students; 21\%).

One $(3 \%)$ probably would inform against a cheating student, two $(5 \%)$ probably would not inform against a cheating student and $36(92 \%)$ would not inform against a cheating student. Students based their answers to the question whether they would inform against a cheating student on the following theories of ethics: deontology (6 students; 15\%), justice (13 students; 34\%), teleology (9 students; $23 \%$ ) and utilitarianism (11 students; 28\%).

Most students (18 people; 46\%) probably would allow another student to copy from them during an examination, $16(41 \%)$ people would allow to copy, three people $(8 \%)$ probably would not allow to copy and two people $(5 \%)$ would not allow to copy. Students based their answers to the question whether they would allow another student to copy from them on the following theories of ethics: deontology (7 students; 18\%), justice (13 students; $34 \%$ ), teleology (6 students; $15 \%$ ) and utilitarianism (13 students; 33\%).

Eleven $(28 \%)$ of the respondents would ask for help from another student during an examination, 20 (51\%) probably would ask for help, five (13\%) probably would not ask for help and three (8\%) would not ask for help. Students based their answers to the question whether they would ask for help from another student during an examination on the following theories of ethics: deontology (10 students; 26\%), justice (11 students; 28\%), teleology (3 students; $8 \%$ ) and utilitarianism (15 students; 38\%).

Among the actions that are considered the least ethical for students, 24 students (62\%) selected informing against another student for cheating or copying of a course project/homework, 13 respondents $(33 \%)$ selected copying of homework or a course project and only two people (5\%) selected cheating during an examination (Fig. 3 (left)).

Analysis of Codes of Ethics of students from other universities showed that such examples of inappropriate student's behaviour as denunciation of another student for cheating or copying of course projects or homework were absent. Thus, according to the Students' Code of Ethics, such behaviour would be ethical; however, the majority of students not only would never inform against another cheating student (97\%) but also consider it to be the least ethical student's behaviour (62\%).
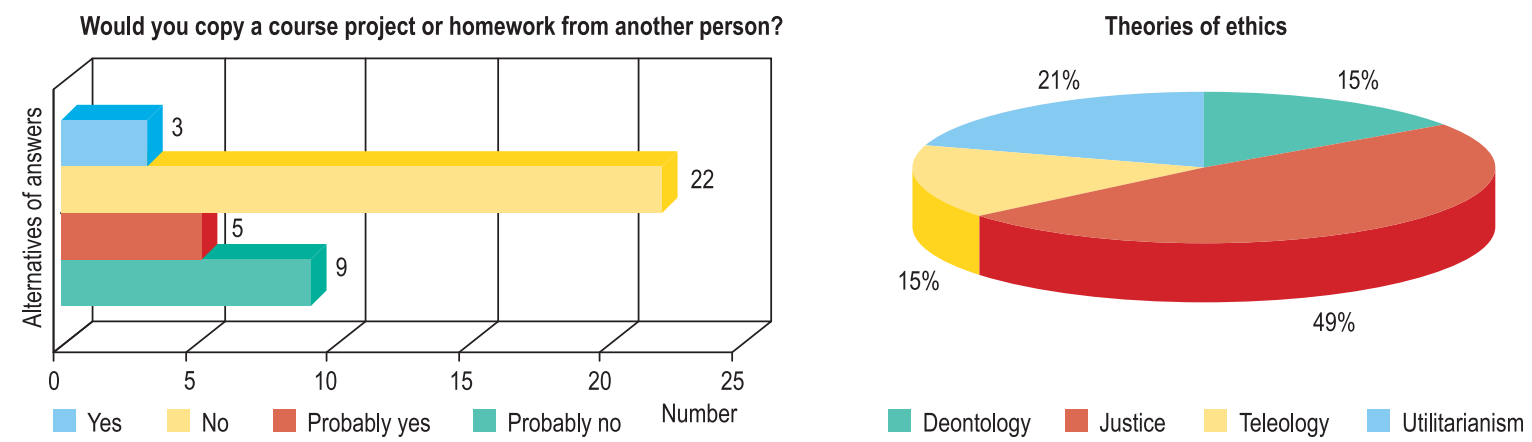

Fig. 2. Copying of a course project or homework (on the left) and theories of ethics selected by the students (on the right) 

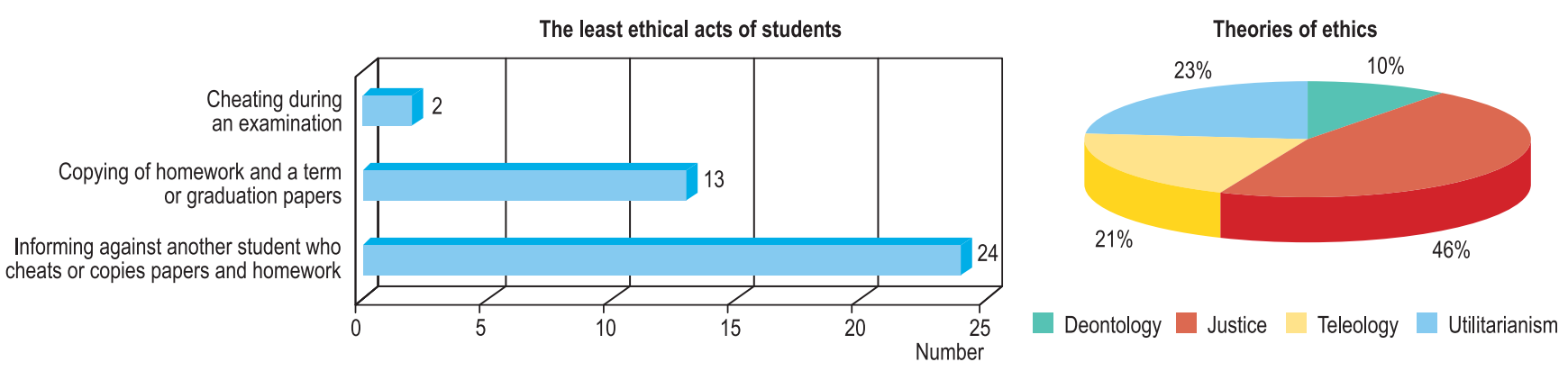

Fig. 3. The least ethical acts of students (on the left) and theories of ethics selected by the students (on the right)

Students based their answers to the question about the least ethical acts of students on the following theories of ethics (Fig. 3 (right)): deontology (4 students; 10\%), justice (18 students; 46\%), teleology ( 8 students; $21 \%$ ) and utilitarianism (9 students; 23\%). Analysis of Codes of Ethics of students from other universities showed that such examples of inappropriate student's behaviour as denunciation of another student for cheating or copying of papers or homework were absent. Thus, according to the Students' Code of Ethics, such behaviour would be ethical according to all or the majority of theories of ethics.

Two (5\%) students would bribe a lecturer to pass an examination, four $(10 \%)$ probably would bribe, eight (21\%) probably would not bribe and 25 (64\%) would not bribe. To summarise, six students $(15 \%)$ would bribe a lecturer in certain circumstances and 33 students $(85 \%)$ would not bribe.

In December 2003, Group for Social Analysis surveyed students from Lithuanian higher education institutions on corruption. The sample of the survey included 14 universities and 25 colleges. $33 \%$ of students who participated in the survey admitted to giving a bribe to a lecturer and $6 \%$ bribed staff of higher education establishments. First and second year students are the most bound to bribe a lecturer (Education against corruption 2004). Students based their answers to the question about bribing a lecturer on the following theories of ethics: deontology (8 students; $21 \%$ ), justice (20 students; 51\%), teleology (6 students; $15 \%$ ) and utilitarianism (5 students; $13 \%$ ).

Six distance learning students (15\%) would agree to pay for preparation of homework, a course project or a graduation thesis, $10(26 \%)$ probably would agree, eight (20\%) probably would not agree and $15(39 \%)$ would not agree (see Fig. 4 (left)). To summarise, 16 students (41\%) would agree to pay for preparation of homework, a course project or a graduation thesis in certain circumstances and 23 students (59\%) would not agree.

We see the following inviting offer in the website of the company "Auksine Plunksna" which offers graduation theses for sale: "Our country's situation makes students work while studying in order to earn a living and to pay for education, which becomes more and more expensive each year. Therefore, the studies suffer, and it becomes more difficult to find a balance in life. What are the choices? To postpone the graduation thesis to the next year or to complete the studies nevertheless?". Without a context, we could think that this company does not suggest ordering a graduation thesis but offers consulting services on specific studying issues instead. In fact, a student who uses services of this or other companies is not a passive observer. He/she must submit exact information about his/her faculty to the company and specify the requests and remarks of his lecturer, the
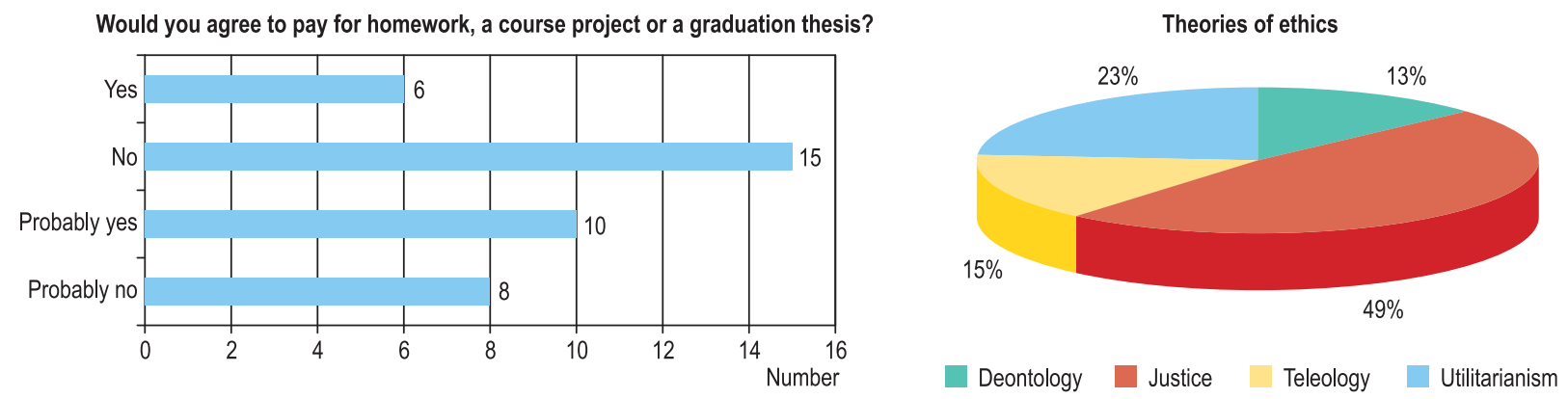

Fig. 4. Payment for homework, a course project or a graduation thesis (on the left) and theories of ethics selected by the students (on the right) 
academic adviser, in the course of preparation of the thesis: "The thesis will be written gradually, its parts will be corrected by your academic adviser, thus we grant quality and high evaluation. Practically, the academic adviser is the guarantee of quality: his/her pieces of advice will determine the contents of the thesis".

These increasingly spreading phenomena cause obvious concerns. Not because of cheating the lecturers and administrations of higher education institutions but mostly because such acquisition of diplomas is based on a peculiar "clear conscience". Advertisements of such service companies do not hint on the fact that those who use their services would not be able to get such or even a better diploma with own efforts. The students who earn their grades through efforts of other people probably do not encounter any moral dilemma. Hardly ever they doubt their ability to complete higher education independently, "if they would study", "if they had time to learn", "if they were not forced to earn their living". Thus the circumstances, the general situation of studies and other problems as if not subjected to the student's conscience are the biggest culprit in this case. The process of studies becomes a most primitive relationship of product exchange based on laws of time saving. Graduation theses are written by those who have time and are acquired by those who can pay for them. Moral issues are usually disregarded in a market (Daugirdas 2005).
Students based their answers to the question whether they would agree to pay for homework, a course project or a graduation thesis on the following theories of ethics (Fig. 4 (right)): deontology (5 students; 13\%), justice (19 students; 49\%), teleology (6 students; 15\%) and utilitarianism (9 students; 23\%).

Among the top penalties for cheating students, one student $(2.6 \%)$ selected a lower grade, three students $(7.7 \%)$ selected increased tuition fees, seven students $(17.9 \%)$ selected public announcement of names of cheaters, 14 students $(35.9 \%)$ selected warning and 14 students $(35.9 \%)$ selected elimination from the university (Fig. 5 (left)). Students based their answers to the question about the top penalties for cheating students on the following theories of ethics (Fig. 5 (right)): deontology (7 students; 18\%), justice (19 students; 49\%), teleology (7 students; 18\%) and utilitarianism (6 students; $15 \%)$.

Table 3 is prepared in order to analyse the ethical theories on which students based their answers during the VEBER online questioning.

The number and the average of students who selected a certain theory have been calculated too. The justice theory of ethics was the most popular among students as basis for their answers (used 187 times; 44\%). The theories of utilitarianism (used 103 times; 24\%) and deontology (used 74 times; 17\%) were used less frequently. And the teleology theory of ethics was the least popular (used 65 times; 15\%; Fig. 6).
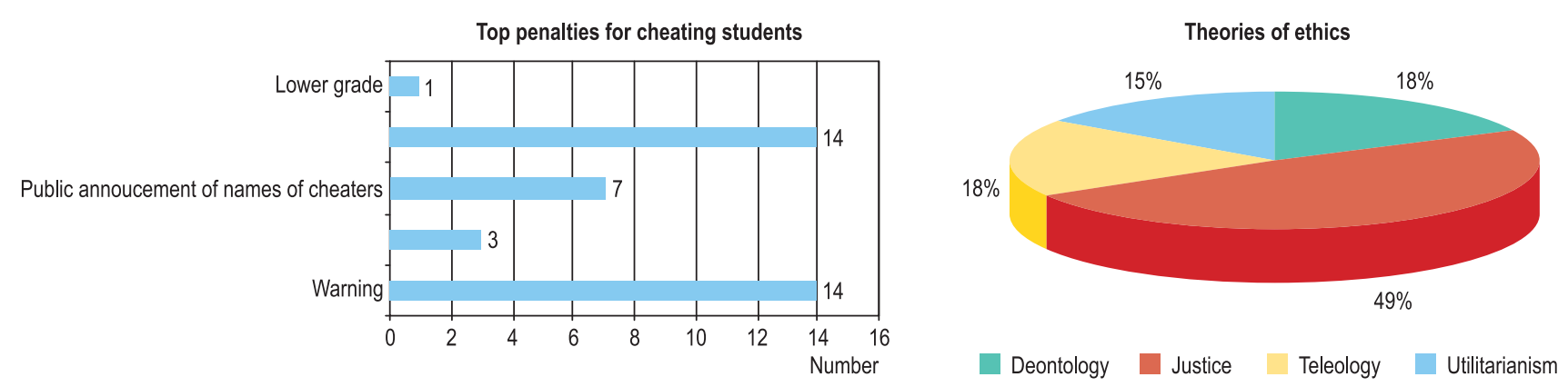

Fig. 5. Penalties for cheating students (on the left) and theories of ethics selected by the students (on the right)

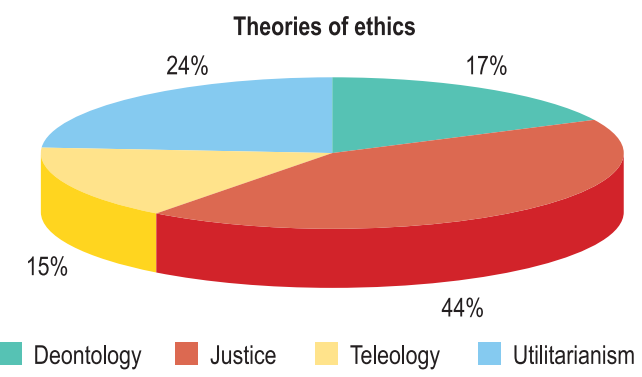

Fig. 6. Theories of ethics selected by the students 
Table 3. Theories of ethics selected by the students

\begin{tabular}{|c|c|c|c|c|c|c|c|c|c|c|}
\hline \multirow{3}{*}{$\begin{array}{l}\text { Question } \\
\text { No. }\end{array}$} & \multicolumn{8}{|c|}{ Theory of ethics } & \multirow{3}{*}{ Total } & \multirow{3}{*}{ Total, $\%$} \\
\hline & \multicolumn{2}{|c|}{ Deontology } & \multicolumn{2}{|c|}{ Justice } & \multicolumn{2}{|c|}{ Teleology } & \multicolumn{2}{|c|}{ Utilitarianism } & & \\
\hline & number & $\%$ & number & $\%$ & number & $\%$ & number & $\%$ & & \\
\hline 3 & 6 & 15 & 23 & 59 & 4 & 10 & 6 & 15 & 39 & 100 \\
\hline 5 & 7 & 18 & 16 & 41 & 7 & 18 & 9 & 23 & 39 & 100 \\
\hline 7 & 6 & 15 & 19 & 49 & 6 & 15 & 8 & 21 & 39 & 100 \\
\hline 9 & 6 & 15 & 13 & 33 & 9 & 23 & 11 & 28 & 39 & 100 \\
\hline 11 & 7 & 18 & 13 & 33 & 6 & 15 & 13 & 33 & 39 & 100 \\
\hline 13 & 10 & 26 & 11 & 28 & 3 & 8 & 15 & 38 & 39 & 100 \\
\hline 15 & 8 & 21 & 16 & 41 & 3 & 8 & 12 & 31 & 39 & 100 \\
\hline 17 & 4 & 10 & 18 & 46 & 8 & 21 & 9 & 23 & 39 & 100 \\
\hline 19 & 8 & 21 & 20 & 51 & 6 & 15 & 5 & 13 & 39 & 100 \\
\hline 21 & 5 & 13 & 19 & 49 & 6 & 15 & 9 & 23 & 39 & 100 \\
\hline 23 & 7 & 18 & 19 & 49 & 7 & 18 & 6 & 15 & 39 & 100 \\
\hline Average & 7 & 17 & 17 & 44 & 6 & 15 & 9 & 24 & 39 & 100 \\
\hline Sum: & 74 & & 187 & & 65 & & 103 & & & \\
\hline
\end{tabular}

\section{Conclusions}

In order to humanize VGTU distance studies and to strengthen their ethical nature, the VEBER online questionnaire was implemented and the Web-based Model of Multiple Criteria Ethical Decision-Making for Ethical Behaviour of Students developed within the project EURASIA; the latter was used as a basis for the development of E-DS System. Besides, the performed research allows to make different conclusions. For example, today's students are more concerned about the reaction of their contemporaries and the university administration to the norms of honest behaviour promoted by staff and administration than about the norms themselves. Indeed, students expect the university administrations to declare how they should become honest, non-cheating and respectful towards teaching and learning. Even when students hear the statements but watch other students cheating and lecturers being tolerant by ignoring, students will take cheating as a means to pass an exam with a better possible mark. Many students ask: "If lecturers are not concerned about cheating, why should I be?"

\section{References}

Boyer, E. L. 1987. College: The undergraduate experience in America. New York: Harper \& Row.

Bombara, M. J. 2002. Relationships among school counselors' level of moral reasoning, demographic characteristics, and their use of ethical decision-making resources, Dissertation Abstracts International Section A: Humanities \& Social Sciences 62(11-A).

Bowers, W. J. 1964. Student dishonesty and its control in college. New York: Bureau of Applied Social Research, Columbia University.

Brauers, W. K. M.; Zavadskas, E. K. 2006. The MOORA and its application to privatization in a transition economy, Control and Cybernetics 35(2): 445-469.

Corey, G.; Corey, M. S.; Callanan, P. 1998. Issues and ethics in the helping professions (5th). Pacific Grove, CA: Brooks/ Cole.

Cottone, R. R.; Claus, R. E. 2000. Ethical decision-making models: a review of the literature, Journal of Counseling and Development 78(3): 275-283.

Daugirdas, T. 2005. Šešèliniai universitetai [Shadow universities]. Available from Internet: $<$ http://www.lksb.lt/straipsniai/straipsnis-352.htm>. 
Doolittle, N. O.; Herrick, C. A. 1992. Ethics in aging: a decision-making paradigm, Educational Gerontology 18(4): 395-408.

Education against Corruption. The results of the research of corruption in universities. 2004. Available from Internet: $<$ http://www.vpu.lt/sdc/antikorupcija/am1.htm>.

Garfat, T.; Ricks, F. 1995. Self-driven ethical decisionmaking: A model for child and youth care, Child and Youth Care Forum 24(6): 393-403.

Ginevičius, R. 2008. Normalization of quantities of various dimensions, Journal of Business Economics and Management 9(1): 79-86.

Ginevičius, R.; Krivka, A. 2008. Application of game theory for duopoly market analysis, Journal of Business Economics and Management 9(3): 207-217.

Ginevičius, R.; Podvezko, V.; Bruzgè, Š. 2008. Evaluating the effect of state aid to business by multicriteria methods, Journal of Business Economics and Management 9(3): 167-186.

Griene, R. R.; Kropf, N. P. 1993. Ethical decision-making with the aged: a teaching model, Gerontology and Geriatrics Education 13(4): 37-52.

Joseph, V. 1983. Ethics of organisations: Shifting values and ethical dilemmas, Administration in Social Work 7(3/4): $47-57$.

Kaklauskas, A.; Zavadskas, E. K.; Banaitis, A.; Šatkauskas, G. 2007a. Defining the utility and market value of a real estate: a multiple criteria approach, International Journal of Strategic Property Management 11(2): 107-120.

Kaklauskas, A.; Gulbinas, A.; Krutinis, M.; Naimavičienė, J.; Šatkauskas, G. 2007b. Methods for multivariant analysis of optional modules used in teaching process, Technological and Economic Development of Economy 13(3): 253-258.

Kaklauskas, A.; Pruskus, V. 2005. The uses of Internet in the ethical multiple criteria decision-making, Problemos 68: 109-127.

Kaklauskas, A.; Zavadskas, E. K.; Kaklauskienè, J.; Trinkūnas, V. 2003. Ethical multiple criteria decision support web-based system, in Proceedings of the Human Centered Processes Conference, Luxemburg, May 2003.

McCabe, D. L.; Trevino, L. K. 1996. What we know about cheating in college: Longitudinal trends and recent developments, Change 28: 28-33.
Mickaitytė, A.; Zavadskas, E. K.; Kaklauskas, A.; Tumènaite, L. 2008. The concept model of sustainable buildings refurbishment, International Journal of Strategic Property Management 12(1): 53-68.

Mitkus, S.; Trinkūnienè, E. 2008. Reasoned decisions in construction contracts evaluation, Technological and Economic Development of Economy 14(3): 402-416.

Robson, M.; Cook, P.; Hunt, K.; Alred, G., Robson, D. 2000. Towards ethical decision-making in counseling research, British Journal of Guidance \& Counseling 28(4): 533-547.

Shevchenko, G.; Ustinovičius, L.; Andruškevičius, A. 2008. Multi-attribute analysis of investments risk alternatives in construction, Technological and Economic Development of Economy 14(3): 428-443.

Tymchuk, A. J. 1986. Guidelines for ethical decision-making, Canadian Psychology 27: 36-43.

Turskis, Z. 2008. Multi-attribute contractors ranking method by applying ordering of feasible alternatives of solutions in terms of preferability technique, Technological and Economic Development of Economy 14(2): 224-239.

Ustinovichius, L.; Zavadskas, E. K.; Podvezko, V. 2007. Application of a quantitative multiple criteria decision-making (MCDM-1) approach to the analysis of investments in construction, Control and Cybernetics 36(4): 251-268.

Viteikiene, M.; Zavadskas, E. K. 2007. Evaluation of the sustainability of Vilnius city residential areas, Journal of Civil Engineering and Management 13(2): 149-155.

Walden, T.; Wolock, I.; Demone, H. J. 1990. Ethical decision-making in human services: A comparative study, Families in Society 71(2): 67-75.

Zavadskas, E. K.; Turskis, Z. 2008. A new logarithmic normalization method in game theory, Informatica 19(2): 303-314.

Zavadskas, E. K.; Kaklauskas, A.; Turskis, Z.; Tamošaitienė, J. 2008a. Selection of the effective dwelling house walls by applying attributes values determined in intervals, Journal of Civil Engineering and Management 14(2): 85-93.

Zavadskas, E. K.; Turskis, Z.; Tamošaitienè, J. 2008b. Contractor selection of construction in a competitive environment, Journal of Business Economics and Management 9(3): 181-187.

Zavadskas, E. K.; Zakarevičius, A.; Antuchevičienė, J. 2006. Evaluation of ranking accuracy in multi-criteria decisions, Informatica 17(4): 601-618. 